\title{
A new record of Oxychilus alliarius (Gastropoda: Zonitidae) with the species distribution in the Czech Republic
}

\author{
JiTKA HoRÁČKOVÁ ${ }^{1} \&$ LUCIE JUŘIČKOVÁ \\ ${ }^{1}$ Department of Ecology, Faculty of Science, Charles University in Prague, Viničná 7, CZ-12844 Prague 2, Czech Republic; \\ e-mail: jitka.horackova@gmail.com \\ 2Department of Zoology, Faculty of Science, Charles University in Prague, Viničná 7, CZ-12844 Prague 2, Czech Republic; \\ e-mail: lucie.jurickova@seznam.cz
}

\begin{abstract}
HorÁČKOVÁ J. \& JuŘIČKovÁ L., 2009: A new record of Oxychilus alliarius (Gastropoda: Zonitidae) with the species distribution in the Czech Republic. - Malacologica Bohemoslovaca, 8: 63-65. Online serial at $<$ http://mollusca.sav.sk> 3-December-2009.
\end{abstract}

\begin{abstract}
A new finding of the land snail species Oxychilus alliarius was recorded in the Czech Republic. This West European species was found in the six isolated sites during the last thirteen years always in western part of Bohemia. This paper brings new information on the distribution of Oxychilus alliarius in the Czech Republic.
\end{abstract}

Key words: Mollusca, Czech Republic, river floodplains, faunistic, Oxychilus alliarius

\section{Introduction}

Oxychilus alliarius (Miller, 1822) (Gastropoda: Zonitidae) is a terrestrial snail, widespread in western and northern parts of Europe. Besides isolated occurrences on the islands of the Iceland and British Islands, it is common in the continental part of Europe from West France to North Switzerland, North-West Germany, North Poland, South Norway, Sweden, and Finland. Elsewhere in Scandinavia, it occurs only in greenhouses. It is a mesophilous species of woods, rocks, fields, and occasionally gardens and greenhouses (KERNEY et al. 1983). Having the shell width up to $7 \mathrm{~mm}$, it belongs to one of the smallest species of the genus Oxychilus in Central Europe (Fig. 1). It has a ruddy shell and dark grey or black coloured body in contrast to related similar species $O$. cellarius (light grey or brownish coloured body) and $O$. draparnaudi (blue coloured body). Oxychilus alliarius smells strongly of garlic, hence its species-name. It has been found on six sites (Fig. 2) in the western part of the Czech Republic (JUŘIČKOVÁ \&
LožEK 2003, HLAVÁČ et al. 2003, HorÁČKOVÁ \& DVOŘÁK 2008). The first finding of the species was recorded by LoŽEK (1996) in Getsemanka II Nature Reserve in the Brdy Mts. This paper brings new information on its occurrence in the Czech Republic.

\section{Material and methods}

O. alliarius was collected during the ongoing malacological research of the Ohře River floodplain. Mollusc assemblages were sampled using a standard sampling procedure (CAmeron \& Pokryszko 2005). One person searched by eye in all microhabitats on the site for 30 minutes. Litter samples were taken from four quadrates $(25 \times 25 \mathrm{~cm})$ in the plot of size $10 \times 10 \mathrm{~m}$ at each of sites. Forty-seven sites situated on both river banks in the alluvium of the Ohře River were researched. Nomenclature follows JUŘIČKOvÁ et al. (2008) with several up-to-date changes. The shells are deposited in the collection of the first author.
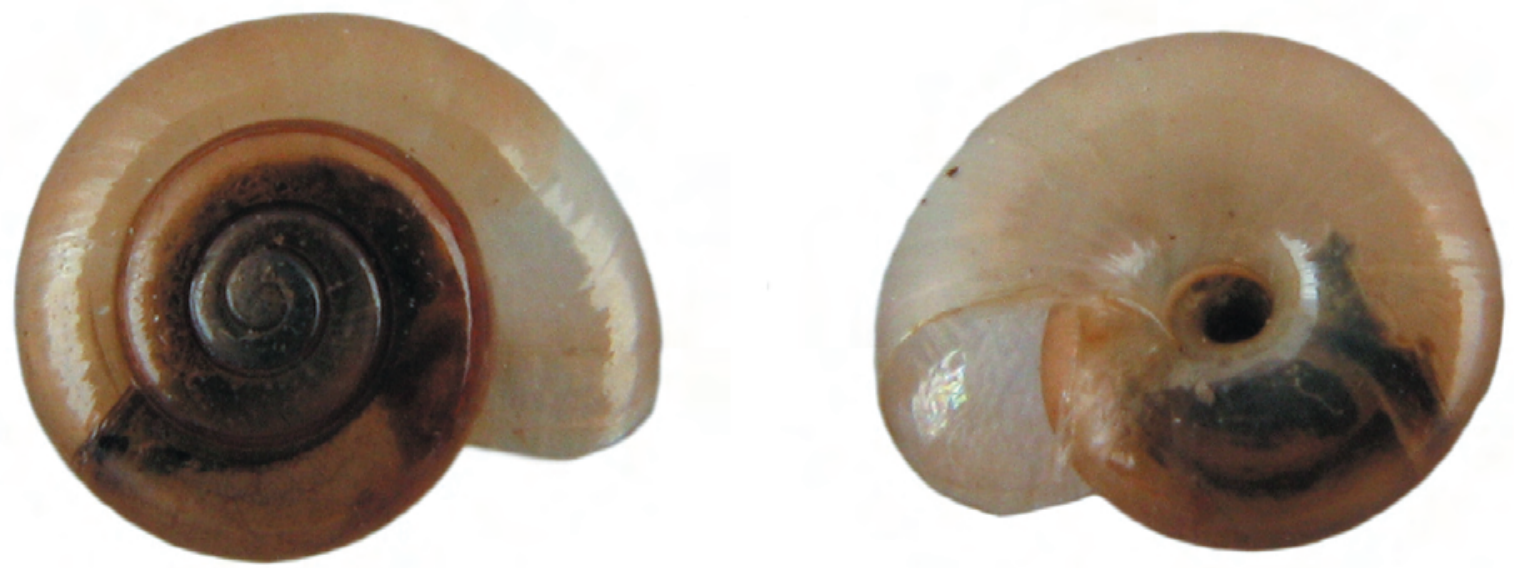

Fig. 1. Shell of Oxychilus alliarius (Miller, 1822) from the Ohře River floodplain (West Bohemia); height $=1.9 \mathrm{~mm}$, width $=5.0$ mm. Photo: Jitka Horáčková. 


\section{The list of sites}

List of known sites of Oxychilus alliarius in the Czech Republic is given. Data in the site list as follows: number of the site, geographical co-ordinates in WGS-84 system, quadrate number of faunistic mapping according to PRUNER \& MíkA (1996), elevation (m a.s.1.), name of the nearest settlement, descripition of the habitat, date of the research, number of living individuals or empty shells.

1. 493'5" N, 1345'10" E, 6448b, 690 m, Míšov near Rožmitál pod Třemšínem, Nature Reserve of Getsemanka II in the Brdy Mts., mesic submontane deciduous forest, 20 May 1993 (JuŘIČKOVÁ \& LožEK 2003).

2. $49^{\circ} 56^{\prime} 29^{\prime \prime} \mathrm{N}, 13^{\circ} 08^{\prime} 58^{\prime \prime} \mathrm{E}, 6044 \mathrm{~d}, 615$ m, Umír village near Plachtín, cellar in the ruins of a house, 13 specimens (9 of them living), 7 July 1996 (JuŘIČKOVÁ \& LožEK 2003).

3. 4956'53" N, 1303'13" E, 6044c, 650 m, Kejšovice near Úterý, humid ditch with bushes, 3 living specimens, 21 August 2002 (JUŘičKOVÁ \& LožEK 2003).

4. 49॰41'29.64" N, 1244'20.02" E, 6342a, 505 m, Muckov village, farm at north-western outskirts of the village, 4 living specimens, 18 May 2003 (HlavÁč et al. 2003).

5. 49³2'44.5" N, 12³6'09.3" E, 6441d, $784 \mathrm{~m}$, a former village of Pleš, the ruins of a church and an old cemetery, 16 August 2007 - 4 living specimens, 1 May 2008 - 3 living specimens (HorÁČKOVÁ \& DVOŘÁK 2008).

6. 50॰11'03.10" N, 1242'54.00" E, 5842a, 391 m, Staré Sedlo near Sokolov, softwood forest with ruins of a building in the alluvium of the Ohře River, 27 July 2008 - 2 living specimens, Jitka Horáčková.

\section{Results and discussion}

Oxychilus alliarius was found only at one site (site no. 6, Fig. 2) in the alluvium of the Ohře River at the outskirts of Staré Sedlo village near Sokolov (Karlovy Vary district, West Bohemia). On July 27, 2008, two living specimens were found in a litter sample. The habitat is covered by an alluvial hardwood forest with a rich herb layer dominated by Urtica dioica, Aegopodium podagraria, Gallium aparine, Stellaria nemorum, and Rubus caesius. Despite the almost natural present character of the habitat, the building ruins are situated here. Along with Oxychilus alliarius following species were present: dominant species Carychium minimum (29\%), Monachoides incarnatus (13\%), Vitrina pellucida (10\%), Perpolita hammonis (10\%) and additional species as Arion lusitanicus, Eucobresia diaphana, Arianta arbustorum, Cepaea hortensis, Limax cinereoniger, Malacolimax tenellus, Discus rotundatus, Urticicola umbrosus, Alinda biplicata, Semilimax semilimax, Succinea putris, Trochulus hispidus, Columella edentula, Carychium tridentatum, Vallonia costata, Cochlicopa lubrica, Punctum pygmaeum, Vertigo pygmaea, Zonitoides nitidus. This site is the northernmost and lowest $(391 \mathrm{~m})$ locality of $O$. alliarius in the Czech Republic. Every other sites were situated more southern at altitudes above $500 \mathrm{~m}$. The scattered localities in western Bohemia related to the distribution of this species in western Europe. The nearest abroad sites are known in Silesia and Saxony (East Germany). Except the first finding of $O$. alliarius from Getsemanka II Nature Reserve (LožEK 1996), the other Czech sites support a synantropic character of this species.

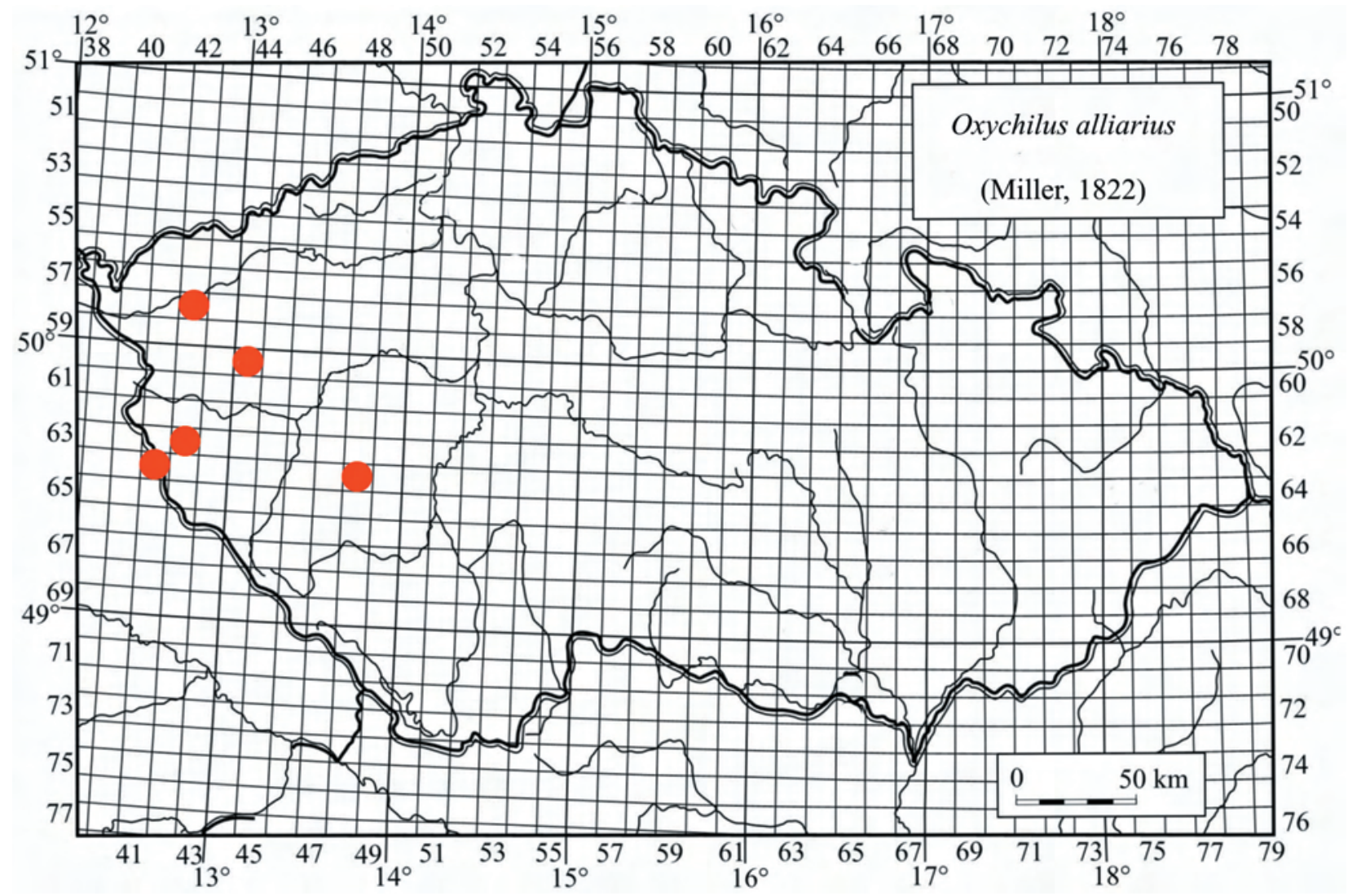

Fig. 2. Known distribution of Oxychilus alliarius in the Czech Republic. 
The populations of Umír village (site no. 2) became completely extinct in 2000 (JUŘIČKOVÁ \& LOŽEK 2003). The repeatedly monitored population in Muckov village (2008, 2009; site no. 4) was probably extinct too.

$O$. alliarius has the eastern boundary of its distribution in the Czech Republic. Although this species is very common in the main area of its distribution, populations on the distribution boundary seem to be more susceptible to disturbance.

\section{Acknowledgement}

The research was supported by the project of the Grant Agency of Charles University GA UK no. 40007 and MSMT project 0021620828.

\section{References}

Cameron R.A.D. \& Pokryszko B. M., 2005: Estimating the species richness and composition of land mollusc communities: problems, consequences and practical advice. - Journal of Conchology, 38: 529-548.

Hlaváč J.Č., Beran L., Dvořák L., Horsák M., JuŘičKová L. \& VRabec V., 2003: Měkkýši Českého lesa - III. Kateřinská kotlina a severní část Čerchovského lesa (západní Čechy)
[Molluscs of the Český Les Mts. - III. Kateřinská kotlina and northern part of Čerchovský les (Western Bohemia)]. - Silva Gabreta, 9: 145-166.

HorÁČKovÁ J. \& DvořÁk L., 2008: Měkkýši Českého lesa - IV. Nové údaje pro jižní část Českého lesa [Molluscs

of the Český Les Mts. - IV. New data for the southern part of the Český Les Mts.]. - Malacologica Bohemoslovaca, 7: 81-92, online serial at $<$ http://mollusca.sav.sk $>1$-Oct-2008.

JUŘIČKOVÁ L. \& LOŽEK V., 2003: Oxychilus alliarius (Gastropoda: Zonitidae) in the Czech Republic. - Acta Soc. Zool. Bohem., 67: 183-184.

JuŘičKová L., Horsák M., Beran L. \& DvoŘÁK L., 2008: Check-list of the molluscs (Mollusca) of the Czech Republic. - http:// mollusca.sav.sk/malacology/checklist.htm (last update: $26 \mathrm{Au}-$ gust 2008)

Kerney M.P., Cameron R.A.D., JungBluth J.H., 1983: Die Landschnecken Nord- und Mitteleuropas. - Hamburg-Berlin: Paul Parey, $384 \mathrm{pp}$.

LožEK V., 1996: Oxychilus alliarius v Čechách [Oxychilus alliarius in Bohemia]. - Živa, 44: 76.

Pruner L. \& Míka P., 1996: Seznam obcí a jejich částí v České republice s čísly mapových polí pro sítové mapování fauny [List of settlements in the Czech Republic with associated map field codes for faunistic grid mapping system]. - Klapalekiana, 32 (Suppl.): 1-115 (in Czech). 